Academic Platform Journal of Engineering and Science

\title{
Demir Çelik Endüstrisinde Torpido Taşıma Sistemi Benzetimi
}

\author{
${ }^{1}$ Sena Azdemir, ${ }^{2}$ M. Fatih Ballı, ${ }^{1}$ Muhammet Erikli, ${ }^{* 1}$ Çağrı Sel \\ ${ }^{1}$ Karabük Üniversitesi, Mühendislik F., Endüstri Müh. Böl., Karabük, Türkiye, \\ ${ }^{2}$ KARDEMİR Karabük Demir Çelik Sanayi ve Ticaret A.Ş., Karabük, Türkiye, \\ Araştırma Makalesi \\ Geliş Tarihi: 19.02.2019 \\ Kabul Tarihi: 23.09.2019
}

$\ddot{\mathbf{O z}}$

Demir-Çelik endüstrisinde sürekli üretim söz konusudur. Ham demir cevherini katı çelik formuna getiren birçok firma tam gün aralıksız çalışmaktadır. Bu tür firmaların üretim süreçleri oldukça maliyetli ve zahmetlidir. Sıvı ham demirin sürekli olarak döküm operasyonları arasında taşınması gerekmektedir. Taşımalarda yaşanan aksaklıklar üretici firmanın büyük mali kayıplar yaşamasına sebep olmaktadır. Bu çalışmada; bir demir-çelik firmasında üretilen sıvı ham demirin proses içerisinde taşınması için kullanılan torpidoların verimliliğinin artırılması amaçlanmıştır. Üretim sisteminin olay artırımlı benzetimi yapılmıştır. Üretimde darboğaz yaratan torpidoların kullanılmaması önerilmiştir. Üretime yönlendirilecek torpidolara, çok kriterli karar verme yöntemlerinden biri olan Topsis metodu ile karar verilmiştir. Mevcut sistem ile önerilen yöntem benzetim ortamında kıyaslandığında zaman kaybı \%66,35 oranında azalırken üretim miktarında \%9,06 (ayda ortalama 13.215,33 ton sıvı ham demire karşılık gelen) bir artış sağlanmıştır.

Anahtar Kelimeler: Demir-Çelik Endüstrisi, Sürekli Üretim, Benzetim, Torpido Taşıma Sistemi, Topsis

\section{Torpedo Transportation System Simulation in Iron and Steel Industry}

\author{
${ }^{1}$ Sena Azdemir, ${ }^{2} \mathrm{M}$. Fatih Ballı, ${ }^{1}$ Muhammet Erikli, ${ }^{* 1}$ Çağrı Sel \\ ${ }^{1}$ Karabük University, Engineering F., Industrial Eng. Dep., Karabük, TURKEY \\ ${ }^{2}$ KARDEMIR Karabuk Iron Steel Industry Trade \& Co. Inc., Karabük, TURKEY
}

\begin{abstract}
The Iron and Steel Industry is a process industry and subject to continuous production. In the iron and steel sector, many companies producing solid steel form using raw iron ore work for full-day shifts. Production process is costly and laborious. Liquid iron ore must be continuously transported between the casting operations. Transportation problems cause high financial losses. In this study, we aim to increase the efficiency of torpedoes transferring the liquid steel between the casting operations in an iron and steel company. We introduce an event-based simulation model and propose not using the torpedo causing bottleneck in production. The torpedo used in the production is decided by Topsis method which is a multi-criteria decision-making approach. Comparing to existing system and the proposed approach using the simulation model, it has been observed that production quantity increases by $\% 9,06$ (13.215.33 tons of liquid iron on average per month) while the waste of time decreases by $\% 66,35$.
\end{abstract}

Keywords: The iron and steel industry, continuous production, simulation, torpedo transportation system, Topsis 


\section{GÍRİ̧̧}

Küreselleşen ekonomilerde demir çelik sektörün de talepler her geçen gün artmaktadır. Demir çelik sektöründe artan ürün taleplerini yetiştirmek ve siparişleri zamanında teslim etmek firmaların temel amaçlarındandır. Firmaları, zamanında teslim edilemeyen siparişler, uygulanan yanlış üretim ve envanter politikaları olumsuz etkilemektedir.

Demir çelik endüstrisinde, firmalar üretim miktarını artırmak, üretim süresini kısaltmak ve ürünü zamanında teslim etmek için üretim süreçlerini iyileştirme çabası içerisindedir. Çalışmada ele aldığımız firma, artan üretim hedeflerine paralel olarak teknolojik alanda da yenilikçi bir yol izlemiştir ve 2018 yılında sıcak maden taşıma sistemini değiştirmiştir. 2018 yılı öncesinde, firmada yüksek fırınlarda üretilen sıvı ham demirin taşıma işlemleri potalarla yapılmakta iken 2018 yılından sonra bu taşımalar tamamıyla torpidolarla gerçekleştirilmektedir.

Çalışmanın amacı bu taşıma sistemini verimli hale getirecek öneriler sunmaktadır. Ortaya koyulan en temel öneriler; (i) darboğaz oluşturan, kullanım ömrünü tamamlamış veya yeterli kapasiteye sahip olmayan torpidoların sisteme kabul edilmemesidir, (ii) kullanılacak torpidoların seçilmesi için Topsis metodu ile çok kriterli karar verilmesidir. Şekil 1'de gösterildiği gibi mevcut durum ile önerilerin neticeleri üretim ve taşıma sisteminin olay artırıml benzetimi yapılarak kıyaslanmıştır.

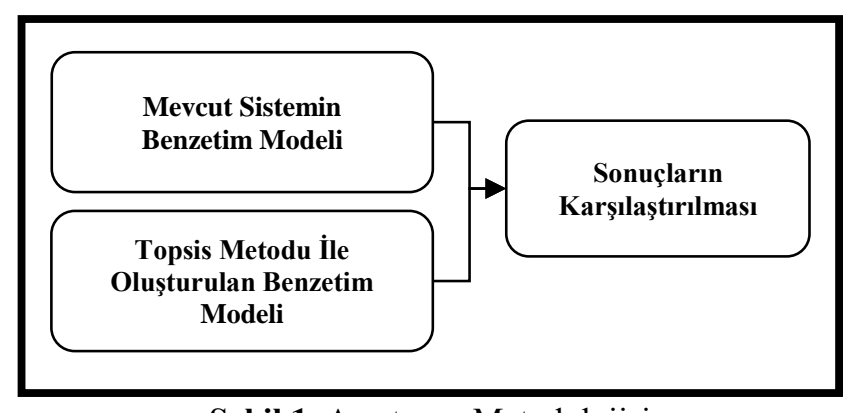

Şekil 1. Araştırma Metodolojisi

Takip eden bölümlerde; Bölüm 2'de literatürde yer alan üretim benzetimi çalışmaları incelenmiştir. Bölüm 3 'te üretim sürecinin ve karşılaşılan problemin detaylı tarifi gerçekleştirilmiştir. Bölüm 4'te sistem benzetimi yaklaşımı açıklanmıştır ve benzetim modeli sunulmuştur. Bölüm 5'te Topsis yöntemi açıklanmıştır ve önerilen senaryo tarif edilmiştir. Son olarak, Bölüm 6'da ve Bölüm 7'de kıyaslamalı sonuçlar verilmiştir ve gelecek çalışmalar tartışılmıştır.

\section{LITERATÜR TARAMASI}

Günümüzde bilgisayar destekli benzetim uygulamaları üretim ve hizmet sektöründe yaygın bir şekilde kullanılmaya başlamıştır. $\mathrm{Bu}$ bölümde ele alınan probleme yönelik literatürde yer alan benzetim uygulamaları incelenmiştir.
Benzetim, bir sistemin davranışlarını modelleyerek inceleyebileceğimiz bir araçtır. Küçükönder ve Uçar [1] çalışmalarında benzetim modellemenin üretim tesislerinde uygulanması durumunda, üretim etkinliği üzerindeki etkisini incelemişlerdir. Sabır ve Batuk [2] çalışmalarında seçilmiş bir boya terbiye işletmesinin üretim maliyeti ve süresi değişken talebe dayalı olarak, orta ve kısa dönemli planlama için benzetim yöntemiyle modellemişlerdir. Gerçek veriler kullanılarak boya terbiyede üretim maliyetleri ve üretim süresi hesaplanmıştır. Üretim için gerekli operatör ihtiyacı belirlenmiştir. Boya terbiye işletmelerindeki üretimin maliyet ve süreye dayalı olarak modellenebileceği ve modelin çözülebileceği ortaya koyulmuştur.

Benzetim, sanal bir ortamda sistemin farklı durumlardaki çıktılarını gözlemlememizi sağlar. Bir sistemin benzetimini yapıp farklı senaryolar oluşturularak en iyi senaryoyu görebiliriz. Koruca'nın [3] çalışmasında, kriz ortamında esnek benzetim vardiya planı geliştirmeyi amaçlanmıştır. Bu çalışmada Fabrika Organizasyonu Benzetim Yöntemi (Faborg-Sim) yazılımından faydalanılarak kalorifer kazanı imal eden bir işletmede vardiya planlama modülü geliştirilmiştir. İşletmenin mevcut veriler ve çalışma sürelerinden yola çıkarak olası kriz ortamlarına uygun dört farklı vardiya planı senaryosunu ele alınmıştır. Benzetim sonuçlarından kapasite kullanım oranları, dolaşım süreleri, süreçte bekleyen işlerin başarımı ve teslimat oranları elde edilmiştir. Mevcut durumda haftada 56 saat çalış1lırken, 1. Senaryoda 45 saat, 2. Senaryoda 40 saat, 3. Senaryoda 35 saat ve 4. Senaryoda 25 saatlik vardiya planları değerlendirilmiştir.

Literatür araştırmamızda farklı senaryolar deneyerek en iyi senaryonun seçilmesinde çok kriterli karar verme yöntemlerini kullanan birkaç çalışma detaylıca incelenmiştir. Bu çalışmalardan biri olan Gül vd. [4], hastane acil departmanlarında ortalama hasta kalış süresini azaltan, hasta verimliliğini (birim zamanda hizmet gören hasta sayısını) artıran, kaynak kullanım oranlarını yükselten ve tüm bunlara bağlı olarak personel seviyesini belirleyen 10 farklı senaryo geliştirmiş̧tir. Bu senaryolar çok kriterli karar verme teknikleri ile değerlendirilmiştir. En iyi senaryo performans ölçütü ağırlıkları Bulanık AHP (Analitik Hiyerarşi Süreci) kullanılarak belirlenmiştir. Senaryolar VIKOR (Vise Kriterijumska Optimizacija I Kompromisno Resenje) ve PROMETHEE (Preference Ranking Organization Method for Enrichment Evaluation) yöntemleri ile sıralanarak birbirleriyle kıyaslanmıştır.

Literatür taramamızda incelenen diğer bazı çalışmalarda hem faklı senaryolar denenmiş hem de istatiksel yöntemler kullanılmıştır. Boyraz [5] çalışmasında, rafineriler, boru hattı, döküm depo, akaryakıtla ilgili birlikler ve tugaylardan oluşan kompleks akaryakıt ikmal sistemini ele almıştır. Lojistik yöneticilerine döküm depo ile tugay arasındaki bölümünde, dağıtım sisteminin kurulması esnasında yardımcı olacak karar destek aracı sunulmuştur. Bunun için Promodel benzetim programında 2 adet tedarik ağ tasarlanmıştır. 5 farklı senaryo, t testiyle \%95 güven 
aralığında istatiksel olarak incelemiştir. Minimum taşıma maliyeti açışından değerlendirdiğinde 2. alternatifin daha iyi sonuç verdiğini ortaya çıkmaktadır. Sonuç olarak, dağıtımın bir kısmının yükleniciler bir kısmının da birlik araçları vasıtasıyla yapılması ile ortaya çıkan karma bir sistem önerilmiştir. Benzer bir çalışmada, Kurşun [6] bir tekstil işletmesinin gömlek dikim hattını ele alarak darboğaz noktaları belirlemiştir. Bu noktalara tezgâh, işçi ekleme çıkarma kararlarıyla hattın dengelenmesi sağlanmıştır ve alınacak yatırım kararlarına destek olacak öneriler sunulmaya çalışılmıştır. Veri analizinde öncelikle iş-zaman etüdü yapılarak hesaplanan işlem sürelerinin bağımsızlığg kontrol etmiştir. İşlem sürelerinin bağımsızlığını kontrol etmek için serpilme diyagramı, otokorelasyon ve koşum testleri uygulanmıştır. Her bir operatörün yaptığg işlem sürelerinin bağımsızlığı kanıtlandıktan sonra, hangi dağılıma uygun olduğunun belirlenmesi için verilerin histogramları çizilmiştir. Stat:Fit programı yardımıyla çizilen histogramların hangi dağılımlara uyduğu tahmin edilmiştir ve Kolmogorov-Smirnov uygunluk testi aracılığıyla tahmin edilen dağılıma uyup uymadığı kontrol edilmiştir. Benzetim modeli Enterprise Dynamics programında kurmuştur. Benzetim sonucunda değerlendirme ölçütleri incelenerek sistemde darboğaz oluşan noktalar tespit etmiştir ve darboğaz oluşan tezgâh gruplarına ekleme yapılarak model üzerinde Seçenek 1, Seçenek 2 ve Seçenek 3 olmak üzere 3 farklı senaryo denenmiştir.

Bağ ve Aslan [7] bir tekstil fabrikasının üretim sisteminin mevcut durumunu analiz etmek için benzetim modeli kurulmuştur. Benzetim programı olarak ProModel 9.2 kullanılmıştır. Kurulan model sayesinde fabrikanın dikiş bölümünün bir gün içerisindeki üretimini bilgisayar ortamında görsel olarak takip etmek ve sayısal analizler gerçekleştirmek mümkün olmuştur. Bu analizler sonucunda hedeflenen üretim miktarının mesai saatleri içerisinde yetiştirilemediği ve bazı makinelerin kullanım oranlarının düşük olduğu tespit edilmiştir. Buna göre iki alternatif senaryo denenerek makine kullanım oranlarını yükseltilmiştir.

Uner vd. [8] çalışmalarında, hem faklı senaryolar denemiş hem de istatiksel yöntemler kullanmıştır. Akış tipi bir üretim sisteminde yüksek seviyede iş gücü kullanarak, fazla miktarda ara-stokla taşıma yapan forkliftler yerine otomatik konveyör sistemleriyle tek yönlü, operatörsüz taşıma yapabilen bir sisteme geçiş incelenmiştir. Analizler ProModel benzetim paket programı kullanılarak gerçekleştirilmiştir. Alternatif tasarımlar, performans kriterlerine göre istatistiksel yöntemler vasıtasıyla mukayese edilmiştir.

Kuvvetli ve Erol [9] ele aldığımız çalışmaya benzer olarak bir malzeme taşıma sitemi incelemiştir. Çalışmada, ağaç ürünleri üretimi yapan bir işletmede üretim sahasındaki iş merkezleri arasındaki malzeme taşıma sistemi ele alınmıştır. Taşıma alternatifleri kesikli olay benzetimi yaklaşımıyla değerlendirilmiştir. Sonuçlara göre, konveyör sistemlerinin kullanımının istatistiksel olarak anlamlı olduğunu tespit edilmiştir.

Oleghe ve Salonitis [10] çalışmalarında, yalın üretim sistemlerinde insan faktörleri ve süreç akış elemanları arasındaki etkileşimi göz önünde bulundurması gereken iyileştirme kararları almak için bir benzetim modeli oluşturmuştur. $\mathrm{Bu}$ çalışma benzetim modelleme sürecini basitleştirmiştir ve model daha esnek hale getirilerek çeşitli yalın üretim problem durumlarında kullanılması sağlanmıştır.

Çolak vd. [11] çalışmalarında, bir konteyner limanındaki darboğazları gidererek en uygun istif planını ortaya koyabilmek için mevcut durumu ve iki alternatif senaryoyu benzetim yoluyla karşılaştırmıştır. Gelen gemiler için boşaltma zamanının azaltılması, taşıyıcı vinçlerin altındaki bekleme sürelerinin kısaltılması ve tüm ekipmanların adil kullanımı için en uygun saha düzeninin belirlenmesi amaçlanmıştır. Böylece, enerji ve işgücü maliyetlerinin azaltılması planlanmıştır. $\mathrm{Bu}$ çalışmaları doğrultusunda ikinci senaryo uygulanırsa, toplam boşaltma süresinin mevcut duruma göre \%31.65 iyileşebileceği gözlenmiştir ve ikinci senaryonun en iyi alternatif olduğu görülmüştür.

Fredman vd. [12], çelik üretim süreçlerinin iki boyutlu matematiksel bir model sunmuştur. Çalışmada, torpido içerisinde çeliğin bekletilme süresi, malzeme seçimi ve refrakter tabaka kalınlıkları gibi bir dizi değişkenin, döküm sırasındaki çelik sıcaklık gelişimine etkileri bakımından incelenebileceği bir model oluşturulmuştur. Bu çalışma ile sıvı çeliğin sıcaklığının, torpido içerisindeki bekleme süresinin ve torpidoya döküm şeklinin torpido içerisinde bulunan refrakter tuğlaları hızla aşındırdığı ve torpidonun ömrünü azalttığı belirlenmiştir.

Guasch vd. [13], bir çelik fabrikasında sıcak çelik bobinlerin demiryolu akışını analiz etmek için renkli bir Petri net kavramsal modeli ve bir Arena benzetim modeli geliştirmiştir. Çalışmada potalar kullanılarak yapılan taşıma sistemi analiz edilmiştir. Taşıma işlemleri gerçekleştirilen demiryolu kaynaklarının miktarını en aza indirmek için demiryolu sistemi üzerine önerilerde bulunulmuştur.

Neumann [14], malzeme taşıma sisteminin başa çıkabileceği maksimum yükü tahmin etmek, yük sınırındaki sistemin performansını engelleyen darboğazları analiz etmek ve tasarımını veya öğelerini değiştirmeden sistem performansını iyileştirmek için bir benzetim modeli kullanmıştır.

Yao ve Zhu [15] çalışmalarında, sürekli döküm ile demir/çelik üretiminin ve bu üretime ilişkin lojistik sistemin benzetimini yapmıştır. Üretim çizelgeleme için görsel bir model önermek amacıyla, FlexSim benzetim yazılımını temel almıştır. FlexSim benzetim yazılımı uygulama metotlarının detaylı analizi yapılmıştır. Demir/çelik üretiminin benzetim modelinin oluşturulmasında, endüstriyel üretim özelliklerine dayalı benzetim sistemi mimarisi inşa edilmiştir. Daha sonra gerçek verilerle bir 
demir/çelik ürünü olan SCC üretim sürecinin benzetim modeli oluşturulmuştur.

Coelho vd. [16] yaptıkları çalışmada, entegre bir çelik üretim tesisinde cevher stoklarını kontrol eden ekibin karar vermesine yardımcı olayı amaçlamaktadır. Operasyonel bir bakış açısı ile üretim süreci ile ilgili farklı hammaddelerin alınması, boşaltılması, stoklanması, taşınması ve tedarik edilmesi işlemlerini göz önünde bulundurarak ham madde kullanımına ilişkin bir simülasyon modelinin tasarımı ve uygulanmasını gerçekleştirmiştir.

Mukherjee vd. [17] entegre bir çelik tesisinin bir hammadde taşıma sisteminin kapasitesi belirlenmeye çalışmıştır. Kesikli olay benzetimi kullanarak, boşaltma ekipmanlarının kullanımını en üst düzeye çıkarmak, sistem genelinde tıkanıklığı ve darboğazları ele almak ve sorunsuz malzeme akışını sağlayacak şekilde rota düzenini iyileştirmek amaçlanmıştır. Benzetim modeli, demiryolu ağlarındaki tıkanıklığı yönetmeye imkân sunmuştur ve maliyetlerde önemli bir düşüş göstermiştir, dolayısıyla geleneksel yaklaşıma kıyasla daha yüksek yatırım getirisi elde edilebilmektedir. Bu literatür taraması Türkiye'deki Demir Çelik sektörüne yönelik benzetim araştırmalarının eksikliğini ortaya çıkarmıştır. Diğer sektörlerde olduğu gibi Demir Çelik sektöründe de malzeme taşıma sistemlerinin üretim verimliliğine etkisi benzetim modelleri üzerinden analiz edilmelidir. Çalışmamız, literatürdeki bu boşluğu doldurarak Demir Çelik endüstrisinde üretim ve taşıma süreçlerindeki aksaklıkları azaltması açısından bilime ve sanayiye katkı sağlamaktadır.

\section{PROBLEMIN TANIMI}

Demir-Çelik endüstrisinde ilk olarak sıvı ham demir üretim işlemi, yüksek fırınlarda gerçekleşmektedir. Demir cevherinin eritilmesi akabinde ortaya çıkan sıvı ham demir, sıvı çelik formuna getirilmek için konverterlere aktarılmak üzere maden aktarma çukurlarına nakil edilmektedir. Yüksek firınlar ve çelikhane arası sıvı ham demirin nakil işlemi torpido adı verilen araçlarla gerçekleştirilir. Torpido; gövde, motor kabini ve yürüme grubundan oluşan, iç kısmı yüksek sıcaklığa dayanıklı refrakter tuğla ile örülü araçlardır. Her torpidonun birbirinden farklı taşıma kapasiteleri mevcuttur. Torpidoların taşıma kapasitelerinin farklı olmasının nedeni kullanıma paralel olarak oluşan deformasyondur.

Taşıma sisteminde kullanılan torpidolar ve ortalama kapasiteleri Tablo 1'de verilmiştir. Torpidoların taşıma kapasitelerini büyükten küçüğe doğru sıralandığında en çok 155,16 ton ile 12 . torpido taşımaktadır ve en az kapasiteli torpido ise 65,08 ton ile 18 . torpidodur. Büyükten küçüğe doğru sıralama $12,6,16,4,10,11,8,5,13,14$ ve 18 numaralı torpidolar şeklindedir. Bu torpidoların dişında 1, 2, 3, 7, 9, 15 ve 17 numaralı torpidolar üretimde kullanılamayacak seviyede bir hasara sahip oldukları için sisteme dahil edilmemektedir. Yüksek fırınlardan 2. fırın kullanım ömrünü tamamlaması sebebiyle üretimde kullanılmamaktadır.
Tablo 1. Kullanılan Torpidoların Ortalama Kapasiteleri

\begin{tabular}{cc}
\hline $\begin{array}{c}\text { Sistemde Kullanilan } \\
\text { Torpidolar }\end{array}$ & $\begin{array}{c}\text { Torpido } \\
\text { Kapasitesi } \\
\text { (Ton) }\end{array}$ \\
\hline 4.torpido & 144,67 \\
5.torpido & 102,56 \\
6.torpido & 149,49 \\
8.torpido & 107,47 \\
10.torpido & 141,08 \\
11.torpido & 140,24 \\
12.torpido & 155,16 \\
13.torpido & 101,94 \\
14.torpido & 74,13 \\
16.torpido & 144,83 \\
18.torpido & 65,08 \\
\hline
\end{tabular}

Yüksek firınlar, ön hazırlanmış (fiziksel ya da kimyasal) demirli hammaddelerin (sinter, pelet, cevher) kok fabrikalarında üretilmiş olan metalürjik kokun yakılması sonucunda oluşan CO (karbon monoksit) ile redüklenerek ve oluşan 1sı ile ergitilerek sıvı ham demir üretilmesini sağlamaktadır. Torpidolar, ilk olarak yüksek firınlardan erimiş demir cevherini alır. Yüksek firınlarda dolum işlemi yapılan torpidoların tam dolu olup olmadığı kontrol edilir.

Doluluğu uygun görülen torpidolar bir sonraki işlem için devam ederlerken, doluluğu uygun olmayan torpidolar, yüksek firınlarda bir sonraki döküm açılana kadar bekler. Dolu olan torpidolar yüksek fırından almış oldukları sıvı ham demir cevherini kükürt giderme tesisine nakleder. Kükürt giderme tesisi, yüksek firınlardan gelen madenin içerisinde bulunan kükürdün, kireç, magnezyum ve florit kullanılarak istenilen seviyeye getirildiği yerdir. Burada sıvı ham demir istenilen kükürt kalitesine ulaşır. Torpidolar kükürt giderme işleminden sonra taşıdıkları sıvı ham demiri boşaltmak için maden aktarma çukurlarına gider. Maden aktarma çukurları, Çelikhane içerisinde bulunmakta ve Çelikhane içerisinde bulunan konverterlerin maden ihtiyacını karşılamaktadır.

Maden aktarma çukurlarında bulunan potalara torpidoların içerisindeki sıvı ham demir dökülür, daha sonra içi maden dolu hale gelen potalar vinç yardımıyla çukurlardan alınarak konverterlere boşaltılır. Torpidoların naklini gerçekleştirdiği sıvı ham demiri son işlem olarak maden aktarma çukurlarına boşaltıldıktan sonra verilmesi gereken iki karar söz konusudur. Birinci karar "fırınlar acil torpido bekliyor mu?", ikinci karar ise "torpido içerisinde maden kalıntısı var mı?" şeklindedir. Birinci karar doğrultusunda, yüksek firınların döküm açması sebebiyle torpido ihtiyacı oluşmaktadır. Bu sebeple acil beklenen torpidolar yüksek firınlara gönderilir. Birinci karardan geçen torpidoların ise içerilerinde maden kalıntısı (skal) kalıp kalmadı ğı kontrol edilir.

Torpidoların içerisinde maden kalıntısı varsa, torpidoların içerisindeki refrakter tuğlaların aşınmasını engellemek ve kapasitesini olumsuz etkilememek amacıyla Kişpit istasyonuna gönderilir. Kişpit, torpidoların içerisinde kalmış olan maden kalıntılarının temizleme işleminin yapıldığ istasyondur. Kişpit istasyonuna gitmesine gerek duyulmayan torpidolar ise tekrar firınlara gönderilir. Kişpit istasyonunda 
torpidoların içerisindeki bulunan maden kalıntıları oksijen üflenerek kırıcılarla temizlenir ve üretime nakledilmek üzere hazır halde bekletilir.

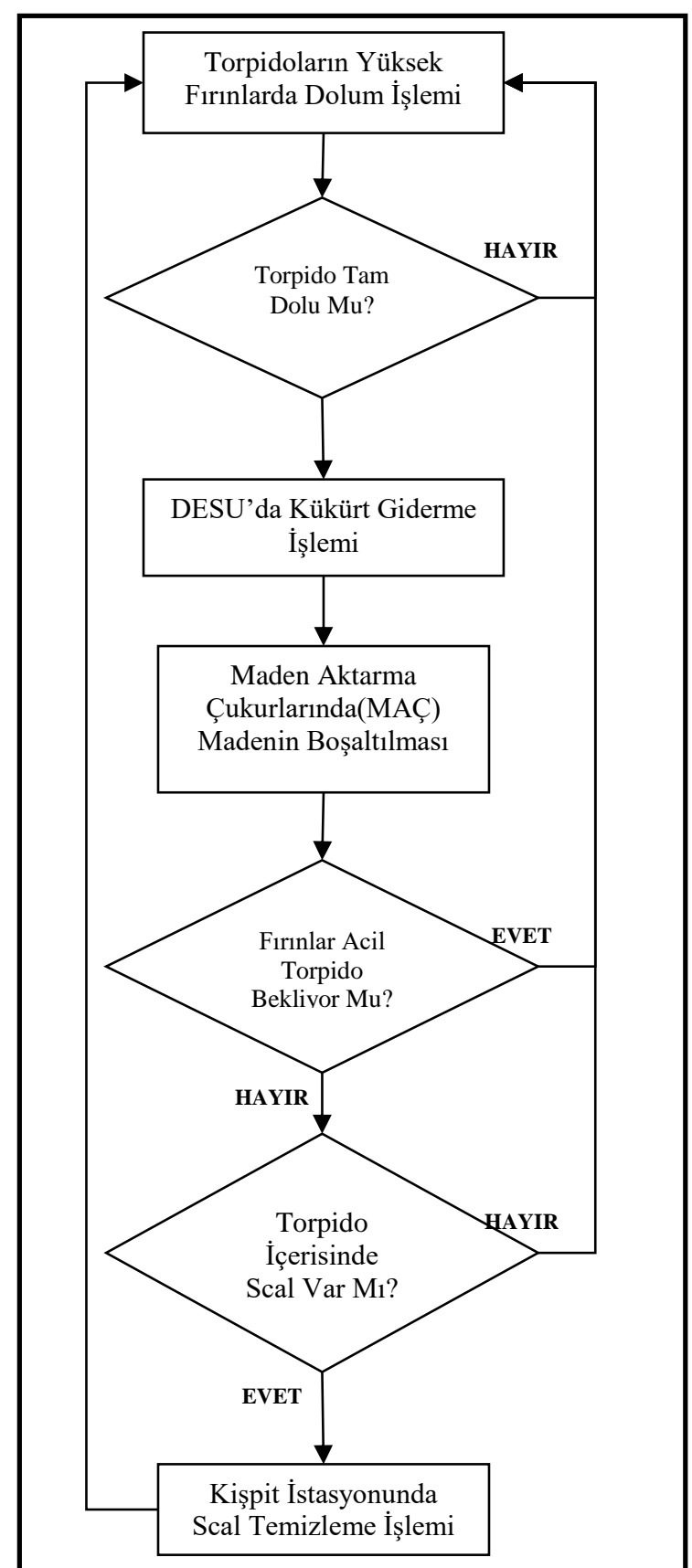

Şekil 2. Sıv1 Ham Demir Üretiminin Proses Şeması

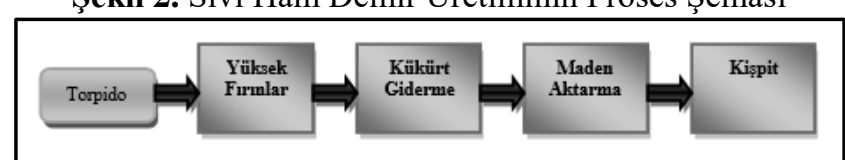

Şekil 3.Sırasıyla Sıvı Ham Demir Nakledilen Tesisler

$\mathrm{Bu}$ işlem 24 saat aralıksız çalışan bir nakil işlemidir. Sistemin proses şeması Şekil 2'de gösterildiği gibidir. Sitemin genel işleyişi ise Şekil 3'de tesis (istasyon) sıralaması ile temsil edilmiştir. Her üretim tesisi elindeki kaynakları en verimli şekilde kullanmayı amaçlar. Verimliliği yükseltebilmenin en önemli kriteri, sistemlerde oluşan zaman kayıplarını yok etmek veya minimuma indirmektir. Zaman kayıpları doğrudan gecikmelere yol açmakta ve büyük mali kayıplara neden olmaktadır. Bu çalışmanın amacı, zaman kayıplarını minimize ederek torpido kullanım sayılarını arttırıp daha fazla miktarda sıvı ham demirin nakil işlemini gerçekleştirebilmektir. Nakil süreci içerisinde, maden aktarma çukurlarında bir darboğaz söz konusudur. İçerisinde bulunan sıv1 ham demiri boşaltmak için gelen torpidolar, maden aktarma çukurlarının önünde beklemektedirler. Torpidonun sıv1 ham demiri yüksek firınlardan aldıktan sonra maden aktarma çukurlarına ulaştırana kadarki süreçte oluşan zaman kayıpları hem torpidonun kullanım ömrünü azaltmakta hem de sistemi yavaşlatmaktadır. Çalışmada mevcut durumda oluşan zaman kayıplarını ve önerilen sistemin uygun olup olmadığını anlayabilmek amacıyla benzetim yöntemi kullanılmıştır. Şekil 4'de görüldüğü gibi ilk adım olarak mevcut sistemin verileri elde edilmiştir. Bu veriler doğrultusunda sistemin birebir benzetiminin yapılmış, oluşan darboğazı engellemek amacıyla sisteme uygun olan torpidoyu seçebilmek için çok kriterli karar verme yöntemlerinden olan Topsis metodu kullanılmıştır ve yeni bir senaryo oluşturulmuştur.

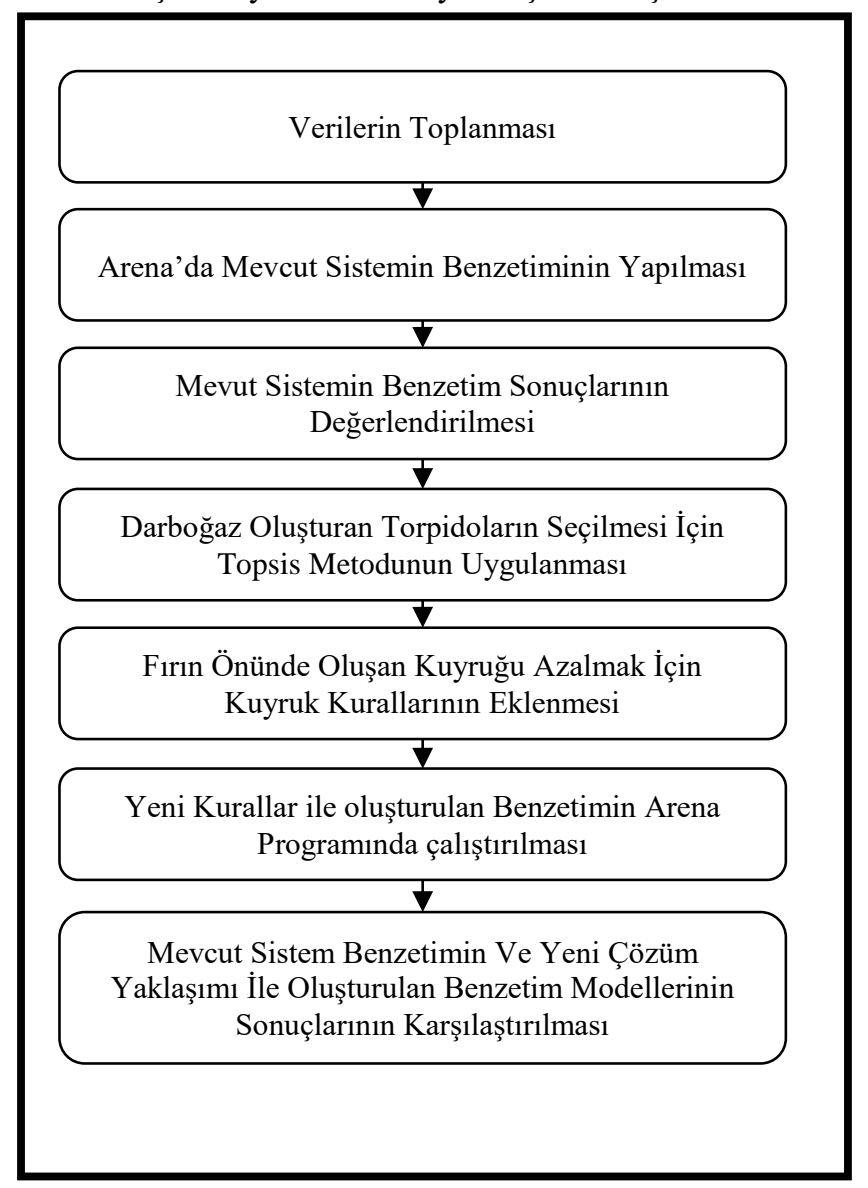

Şekil 4.Problemin Çözüm Aşamaları

\section{BENZETIM VE MODELLEME}

Benzetim gerçek hayatın karmaşı sistemlerinin modellenmesi ve analizinin edilmesinde kullanılan yaygın bir yöntemdir [18]. Sistemin benzetimi için Arena benzetim 
programından yararlanılmıştır. Mevcut sistemin benzetiminin sonucunda çıkan verilerde maden aktarma çukurlarında aşırı yığılma ve firınlarda oluşan kuyruklar dikkat çekmektedir. Darboğaz oluşan Maden Aktarma çukurlarını rahatlatmak için darboğaz oluşturan torpidoların sisteme kabul edilmemesi sağlanmıştır. Sisteme kabul edilmesi uygun olan torpidoların seçimi için çok kriterli karar verme yöntemi olan Topsis metodundan yararlanılmıştır. Topsis yöntemi Hwang ve Yoon (1981) tarafından geliştirilmiştir, pozitif ideal çözümden en kısa mesafe ve negatif ideal çözümden en uzak mesafe alternatiflerinin seçilmesine dayanan çok kriterli karar verme yöntemlerinden birisidir [19]. Sisteme kabul edilecek torpidoların Topsis metodu ile seçiminden sonra her torpidonun kapasitesinin farklı olması sebebiyle işlemlerin operasyon zamanları sisteme kabul edilecek torpidolara göre güncellenmiştir. Daha sonra Yüksek Fırınlarda oluşan kuyrukları azaltmak için kuyruk formülleri eklenmiştir ve bu sayede torpidoların sistemde daha verimli şekilde kullanılması sağlanmıştır. Bu işlemlerin ardından yine Arena benzetim programı kullanılarak önerilen sistem modeli oluşturulmuştur.

\subsection{MEVCUT SISTEMIN BENZETIM MODELI}

Üretim ve torpido taşıma sisteminin benzetimini oluşturabilmek için sayısal verilere ihtiyaç duyulmaktadır. Operasyon sürelerinin ölçülmesi için üretim süreci yedi gün yirmi dört saat incelenmiştir. $\mathrm{Bu}$ sayede operasyon sürelerinin dağılımları ve torpido kullanım bilgileri elde edilmiştir. Toplamda 378 süreç verisi elde edilmiştir ve Yüksek Fırınlar, Kükürt Giderme, Maden Aktarma Çukurları, Kişpit İstasyonu olmak üzere 4 aşama ayrı ayrı etüt edilmiştir. Ardından, torpidoların gelişler arası süresi, operasyon süreleri ve torpido kullanımlarında alınan kararların oranları hesaplanmıştır. Sürelere ilişkin dağılımlar Arena benzetim programında "Input Analyze" modülü ile tespit edilmiştir. Elde edilen dağılımlar ve dağılım parametreleri Tablo 2'de verilmiştir. Yapılan etüt işleminden sonra "Input Analyze" ile elde edilen dağılımlardan yararlanılarak Arena Programında sistemin benzetimi yapılmıştır.

Tablo 2. İşlem Süreleri Dağı̆lımları

\begin{tabular}{ll}
\hline & Dağılım \\
\hline Torpido Gelişler Arası Süre & 0,0 \\
1.Fırın İşlem Süresi & $15+168 * \operatorname{BETA}(1,112,38)$ \\
3.Fırın İşlem Süresi & $19,5+84 * \operatorname{BETA}(2,281,7)$ \\
4.Fırın İ̧lem Süresi & $\operatorname{NORM}(76,822,5)$ \\
5.Fırın İşlem Süresi & $9+\operatorname{ERLA}(14,92)$ \\
Kükürt Gidermeİşlemi Süresi & $1,5+\operatorname{LOGN}(16,79,96)$ \\
Maden Aktarma İşlemi Süresi & 6+GAMM $(132,41)$ \\
Kişsit İşlem Süresi & 3+LOGN $(22,525,1)$ \\
\hline
\end{tabular}

Mevcut sistemin benzetiminde 5 ayr1 karar noktası bulunmaktadır. Bu karardan I.Karar ile kullanıcı tarafindan sisteme girecek torpidolar ve girmeyecek torpidoların belirlenmesi sağlanmıştır. Kullanılmaya elverişli torpidolar sisteme kabul edilirken, kullanılmayacak durumda olan torpidolar sisteme kabul edilmemektedir. Sisteme 11 torpido kabul edilirken 7 torpido siteme kabul edilmemiştir. Daha sonra torpidoların ortalama kapasite özellikleri benzetim sistemine tanımlanmıştır. Firma sisteme kabul edilen torpidoların hangi firına gideceği sezgisel olarak karar verilmektedir. $\mathrm{Bu}$ sezgisel yöntemin yerine II. Karar da geçmiş verilere bakılarak fırın kullanım oranlarının kullanılmıştır. Tablo 3'de gösterildiği gibi 1. fırın \%20,90, 3 . firın $\% 16,93$, 4.firın $\% 14,02$ ve 5.firın $\% 48,15$ oranında kullanım oranlarına sahiptir. Bu bilgiler ile firın seçiminin yapılması sağlanmıştır. Her bir firın ayrı ayrı ele alınarak hesaplanan işlem süresi dağılım bilgileri dakika baz alınarak girilmiştir ve 4 adet fırın prosesi oluşturulmuştur. Sıvı ham demirin soğumasına engel olmak için sistemdeki tüm operasyonlar ilk giren ilk giren ilk çıkar (FIFO) olarak tanımlanmıştır.

Tablo 3.Mevcut Sistemin Benzetim Modelinin Karar Yüzdeleri

\begin{tabular}{|c|c|}
\hline Karar Adı & Yüzde $(\%)$ \\
\hline II.Karar 1.Firın & 20,90 \\
\hline II.Karar 3.Firın & 16,93 \\
\hline II.Karar 4.Firın & 14,02 \\
\hline II. Karar 5.Firın & 48,15 \\
\hline III.Karar Torpido Dolu & 99,9 \\
\hline III.Karar Torpido Tam Dolu Değil & 0,01 \\
\hline IV.Karar Fırınlar Acil Torpido Bekliyor & 9,26 \\
\hline IV.Karar Fırınlar Acil Torpido Beklemiyor & 90,74 \\
\hline V.Karar Torpido Kişpit'e Gönderilecek & 87,30 \\
\hline V.Karar Torpido Kișpit'e Gönderilmeyecek & 12,70 \\
\hline
\end{tabular}

III. Karar ile Kükürt giderme işlemine gidecek torpidolara karar verilmiştir. Bu karar "torpido dolumu, değil mi?" sorusuna yanıt alındığı kısımdır. Geçmiş verilerde torpidolar çok büyük oranda fırınlardan dolu olarak çıkmaktadır.

Fırınlardan çıkan torpidonun boş olma ihtimali göz ard1 edilmeyerek bu boş olma durumu için \%0,01'lik bir kısım ayrılmıştır. Daha sonra torpidolar kükürt giderme istasyonuna gönderilmiştir. Kükürt giderme istasyonun operasyon süresi $1.5+\operatorname{LOGN}(16,7$ 9,96) olarak tespit edilmiştir. Kükürt giderme istasyonun da işi biten torpidolar sonra demir cevherini boşaltmak için maden aktarma çukuruna gitmektedir. Torpidolar içeresindeki maden geçici depolama alanı olan maden aktarma çukurlarına boşaltılır. $\mathrm{Bu}$ boşaltma işlem süresi dağılım olarak $6+\operatorname{GAMM}(13$, $2,41)$ tespit edilmiştir.

Torpidolar maden aktarma çukurundan sonra IV. Karar ile karşılaşmaktadırlar. Bu karar "Fırınlar acil torpido bekliyor mu?" sorusunun yanıtıdır. Bu karar için geçmiş verilere bakılarak \%90,74 oranla firınlar acil torpido beklememekte iken $\% 9,26$ oranında firınlar acil torpido beklemektedir. Torpidolar IV. Karardan sonra V. Karar ile karşılaşmaktadırlar. V. Karar ise "Torpido Kişpit'e gönderilecek mi?” sorusunun yanıtıdır. Bu karar için geçmiş verilere bakılmış ve Kişpit istasyonuna gitmeye uygun görülme oranı $\% 87,30$ iken Kişpit istasyonuna gönderilmeme oranı ise \%12,70'dir. V. Karar için bu oranlar baz alınarak benzetim tamamlanmıştır ve 31 gün çalıştırılmıştır. 
Torpido taşıma sistemi benzetim şeması Şekil 5'de gösterilmiştir. Mevcut sistemde işlem gören torpido sayıları Tablo 4'te verilmiştir. Çalıştırılan modelde en çok torpido dolduran 572 adet torpido ile firın 5. firındır. En az torpido dolduran firın ise 170 adet torpido ile 4 . fırın olarak çıkmıştır. Toplam işlem gören yanı maden aktarma çukurlarına madeni boşaltan torpido sayısı ise 1209 adettir.

Tablo 4. Mevcut Sistemde İşlem Gören Torpido Sayıları

\begin{tabular}{lr}
\hline Sayaç Adı & Değer \\
\hline 1.Fırında İşlem Gören Torpido Sayısı & 283 \\
3.Fırında İșlem Gören Torpido Sayısı & 190 \\
4.Fırında İşlem Gören Torpido Sayısı & 170 \\
5.Fırında İşlem Gören Torpido Sayısı & 572 \\
Kükürt Gidermede İșlem Gören Torpido Sayısı & 1.214 \\
Maden Aktarmada İşlem Gören Torpido Sayısı & 1.209 \\
Kişpit'te İşlem Gören Torpido Sayısı & 938 \\
\hline
\end{tabular}

Tablo 5'te gösterildiği gibi mevcut sistemde en çok maden boşaltma sayıs1 11. torpido ile 113 adet iken en az maden boşaltma sayısı 13 torpido ile 108 adettir. Torpidoların her birinin taşıyabileceği sıvı ham demir miktarı farklıdır. En çok maden taşıyan 12. torpido iken en az maden taşıyan ise 18. torpido olmuştur. 31 günlük çalışma sonucunda çukurlara boşaltılan toplam maden miktarı ise 145.791,05 ton olarak hesaplanmıştır.

Tablo 5. Mevcut Sistem Benzetiminde Çıkan Döküm Sayıları Ve Kapasiteleri

\begin{tabular}{cccc}
\hline Torpido & $\begin{array}{c}\text { Torpido } \\
\text { Kapasitesi } \\
\text { (Ton) }\end{array}$ & $\begin{array}{c}\text { Döküm } \\
\text { Sayısı } \\
\text { (Adet) }\end{array}$ & $\begin{array}{c}\text { Toplam Dökülen Demir } \\
\text { Miktarı (Ton) }\end{array}$ \\
\hline 4.torpido & 144,67 & 111 & $16.058,37$ \\
5.torpido & 102,56 & 112 & $11.486,72$ \\
6.torpido & 149,49 & 109 & $16.294,41$ \\
8.torpido & 107,47 & 109 & $11.714,23$ \\
10.torpido & 141,08 & 109 & $15.377,72$ \\
11.torpido & 140,24 & 113 & $15.847,12$ \\
12.torpido & 155,16 & 109 & $16.912,44$ \\
13.torpido & 101,94 & 108 & $11.009,52$ \\
14.torpido & 74,13 & 109 & $8.080,17$ \\
16.torpido & 144,83 & 109 & $15.786,47$ \\
18.torpido & 65,08 & 111 & $7.223,88$ \\
\hline Toplam & & & $145.791,05$
\end{tabular}

Tablo 6. Mevcut Sistemde İşlem Gören Torpido Sayıları

\begin{tabular}{lr}
\hline Sayaç Adı & Değer \\
\hline 1.Fırında İşlem Gören Torpido Sayısı & 283 \\
3.Fırında İşlem Gören Torpido Sayısı & 190 \\
4.Fırında İşlem Gören Torpido Sayısı & 170 \\
5.Fırında İşlem Gören Torpido Sayısı & 572 \\
Kükürt Gidermede İşlem Gören Torpido Sayısı & 1.214 \\
Maden Aktarmada İşlem Gören Torpido Sayısı & 1.209 \\
Kişpit'te İşlem Gören Torpido Sayısı & 938 \\
\hline
\end{tabular}

modelde en çok torpido dolduran 572 adet torpido ile firın 5. firındır. En az torpido dolduran firın ise 170 adet torpido ile 4. fırın olarak çıkmıştır. Toplam işlem gören yanı maden aktarma çukurlarına madeni boşaltan torpido sayısı ise 1209 adettir.

Tablo 5'te gösterildiği gibi mevcut sistemde en çok maden boşaltma sayısı 11. torpido ile 113 adet iken en az maden boşaltma sayısı 13 torpido ile 108 adettir. Torpidoların her birinin taşıyabileceği sıvı ham demir miktarı farklıdır. En çok maden taşıyan 12. torpido iken en az maden taşıyan ise 18. torpido olmuştur. 31 günlük çalışma sonucunda çukurlara boşaltılan toplam maden miktarı ise 145.791,05 ton olarak hesaplanmıştır.

Tablo 7. Mevcut Sistem Benzetiminde Çıkan Döküm Sayıları Ve Kapasiteleri

\begin{tabular}{cccc}
\hline Torpido & $\begin{array}{c}\text { Torpido } \\
\text { Kapasitesi } \\
\text { (Ton) }\end{array}$ & $\begin{array}{c}\text { Döküm } \\
\text { Sayısı } \\
\text { (Adet) }\end{array}$ & $\begin{array}{c}\text { Toplam Dökülen Demir } \\
\text { Miktarı (Ton) }\end{array}$ \\
\hline 4.torpido & 144,67 & 111 & $16.058,37$ \\
5.torpido & 102,56 & 112 & $11.486,72$ \\
6.torpido & 149,49 & 109 & $16.294,41$ \\
8.torpido & 107,47 & 109 & $11.714,23$ \\
10.torpido & 141,08 & 109 & $15.377,72$ \\
11.torpido & 140,24 & 113 & $15.847,12$ \\
12.torpido & 155,16 & 109 & $16.912,44$ \\
13.torpido & 101,94 & 108 & $11.009,52$ \\
14.torpido & 74,13 & 109 & $8.080,17$ \\
16.torpido & 144,83 & 109 & $15.786,47$ \\
18.torpido & 65,08 & 111 & $7.223,88$ \\
\hline Toplam & & & $145.791,05$
\end{tabular}

Tablo 8. Mevcut Sistem Benzetiminde Kuyruk Bekleme Süreleri

\begin{tabular}{lr}
\hline Kuyruk Adı & $\begin{array}{c}\text { Kuyrukta Bekleme } \\
\text { Süresi (Dakika) }\end{array}$ \\
\hline 1.Fırının Kuyruğu & 21,55 \\
3.Fırının Kuyruğu & 13,07 \\
4.Fırının Kuyruğu & 10,96 \\
5.Fırının Kuyruğu & 21,29 \\
Kükürt Giderme İşlemi Kuyruğu & 7,23 \\
Maden Aktarma İşlemi Kuyruğu & 235,50 \\
Kişpit Kuyruğu & 17,27 \\
\hline Toplam Bekleme Süresi & 326,87 \\
\hline
\end{tabular}

Tablo 6'ya göre en çok kuyrukta bekleme süresine sahip olan operasyon maden aktarma çukurlarında gerçekleşmektedir. $\mathrm{Bu}$ sebeple maden aktarma çukurlarında darboğaz oluşmaktadır. En fazla kuyrukta bekleme süresine sahip firın ise 1. firındır. Sonuçlara göre en az kuyruk bekleme süresine sahip operasyon kükürt giderme işlemidir. 


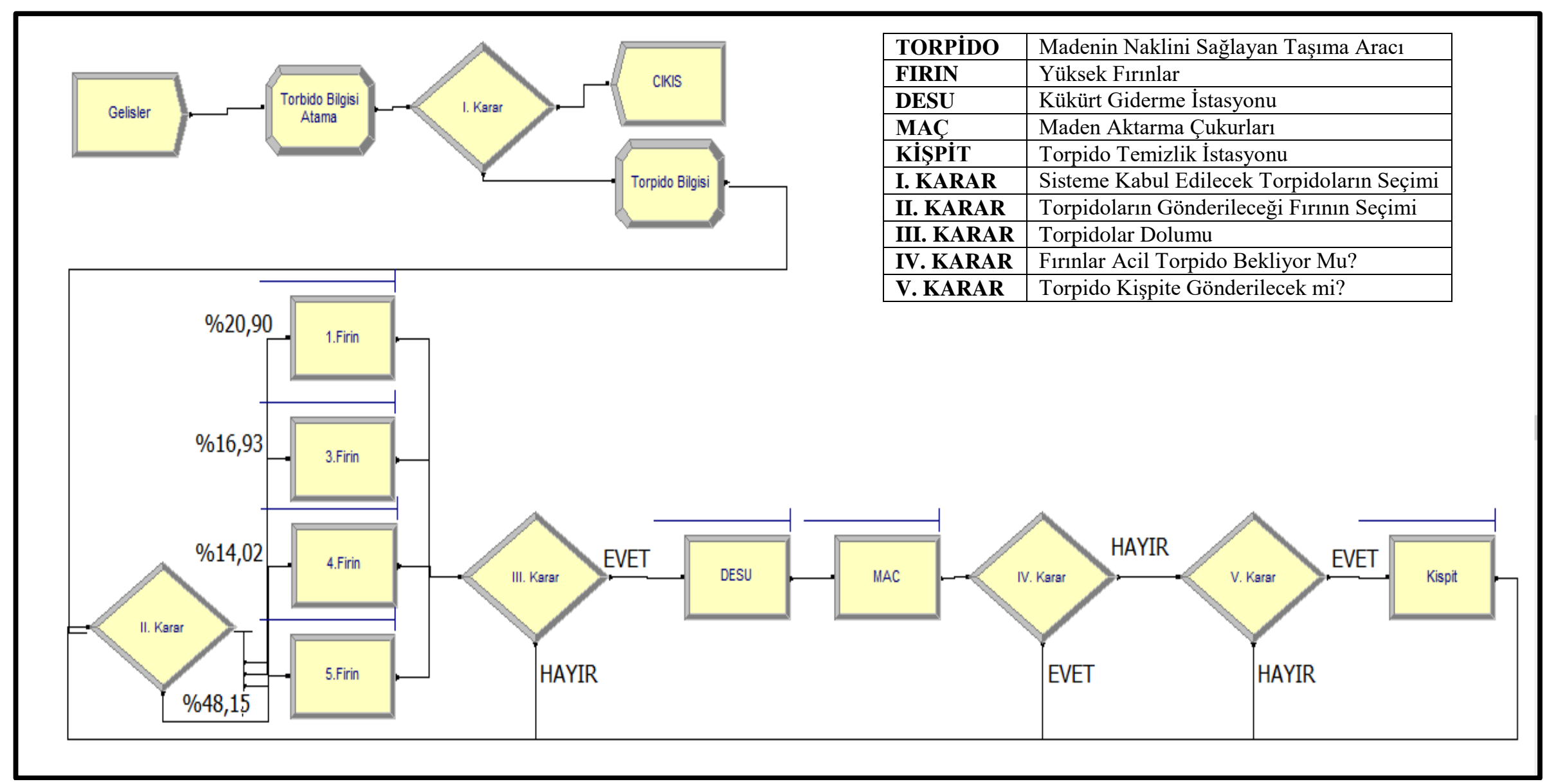

Şekil 5. Torpido Taşıma Sistemi Benzetim Şeması 


\section{TOPSIS METODU İLE ÇÖZÜM YAKLAȘIMI}

Mevcut sistemin benzetimde en çok kuyrukta bekleme süresine sahip olarak dar boğaz oluşsan istasyonun Maden Aktarma Çukurları olduğu görülmüştür. $\mathrm{Bu}$ bekleme sürelerini azaltarak dar boğaz oluşumunu engellemek için mevcut çukurların sayısı attırılması gerekmektedir. Gerçek sistemde çukur sayısını arttırılması belirli kısıtlara ve yüksek maliyetlere sebep olmaktadır. Maden aktarma çukurlarının sayısına müdahale edilemediği için sisteme kabul edilecek torpidolar için öneri sunulmuştur.

Mevcut sistemde toplam 11 torpido çalışmaktadır. $\mathrm{Bu} 11$ torpidonun taşıma kapasiteleri birbirlerinden farklıdır. En çok maden taşıma kapasitesine sahip torpido 155,16 ton ile 12. torpido iken en az maden taşıma kapasitesine sahip olan 65,08 ton ile 18. torpidodur. Kapasiteleri az olup sisteme giren torpidolar maden aktarma çukurlarında kuyruk oluşturmaktadır. Oluşan kuyruklar sebebi ile kapasitesi fazla olan torpidolar kullanım oranları azalmakta ve bu doğrultuda toplam boşaltılan sıvı ham demir miktarını da azalmaktadır. Fırından aldıkları sıvı ham demiri kükürt giderme işleminden sonra boşaltmak için maden aktarma çukurlarına giden torpidolar belirli sürelerde kuyrukta beklemektedirler. $\mathrm{Bu}$ bekleme süreleri doğrultusunda torpidolar içerisindeki madenin sıcaklığı düşmektedir. S1caklık düşünce sıvı ham demir torpido içerisindeki refrakter tuğlaları aşındırmakta ve maden kalıntısı oluşumu gerçekleştirmektedir. $\mathrm{Bu}$ süreç torpidonun kullanım ömrünü azaltmaktadır. Bunun için sistemde dar boğaz oluşturan torpidoları sisteme dahil etmeyerek sistemi daha aktif hale getirmek amaçlanmıştır. Siteme dahil edilmeyecek torpidoların seçimi için çok kriterli karar verme yöntemi seçilmiştir. Çok kriterli karar verme yöntemi problemlerinde karar vericiler, karar değişkeni ve alternatif kümesine göre karar vermektedirler. Karar vericiler için seçim yapılacak, sıralanacak veya sinıflandırılacak faktörler alternatifler olarak isimlendirilmektedir. $\mathrm{Bu}$ alternatiflerin değerlendirilecek nitelikleri ise karar değişkeni olarak adlandırılır [20].

Çalışmada çok kriterli karar verme yöntemi olarak Topsis seçilmiştir. Topsis yönteminde karar verici öznellikten uzaklaşarak bilimsel bir sonuç elde etmektedir.

\subsection{TOPSIS METODU}

Çok kriterli karar verme yöntemlerinden biri olan Topsis yöntemi, nitel bir çevrim yapılmaksızın, doğrudan veri üzerinde uygulanabilmektedir. Topsis yöntemi (1981) Hwang ve Yoon referansı ile Chen ve Hwang tarafindan oluşturulmuştur. Topsis yöntemi rasyonelliği, hesaplamadaki basitliği ve değerlendirme kriterlerinin ağırlıklandırılmasına olanak vermesi gibi avantajları nedeniyle literatürde oldukça fazla kullanılan çok kriterli karar verme yöntemlerinden biridir [21]. Topsis yöntemi 7 adımdan oluşmaktadır. $\mathrm{Bu}$ adımlar ve çalışmada gerçekleştirilen uygulamaları şu şekildedir;
1. Adım: Karar Matrisinin Oluşturulması. Tablo 7'de karar matrisinin yapısı gösterilmektedir.

Tablo 9. Örnek Bir Karar Matrisi

\begin{tabular}{cccc}
\hline \multirow{2}{*}{ ALTERNATÍFLER } & \multicolumn{3}{c}{ ÖZELLIKLER } \\
& $\boldsymbol{y}_{\mathbf{1}}$ & $\boldsymbol{y}_{\mathbf{2}}$ & $\boldsymbol{y}_{\mathbf{3}}$ \\
\hline $\boldsymbol{a}_{\mathbf{1}}$ & $y_{11}$ & $y_{12}$ & $y_{1 k}$ \\
$\boldsymbol{a}_{\mathbf{2}}$ & $y_{21}$ & $y_{22}$ & $y_{2 k}$ \\
$\ldots$ & $\ldots$ & $\ldots$ & $\cdots$ \\
$\ldots$ & $\ldots$ & $\ldots$ & $\ldots$ \\
$\boldsymbol{a}_{\boldsymbol{n}}$ & $y_{n 1}$ & $y_{n 2}$ & $y_{n k}$ \\
\hline
\end{tabular}

2. Adım: Normalize Karar Matrisinin Oluşturulması.

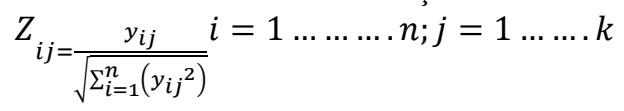

3. Adım: Ağırlıklandırılmış Normalize Karar Matrisinin Oluşturulması.

$$
\begin{aligned}
& X_{i j}=W_{i} * Z_{i j} i=1 \ldots \ldots \ldots n ; j=1 \ldots \ldots k \\
& \text { ( } \left.W_{i} \text { her bir } j \text { kriterinin } a \breve{g} \iota r l ı \breve{g} l\right)
\end{aligned}
$$

4. Adım: $m^{*}$ ve $m^{-}$İdeal Noktalarının Tanımlanması.

$$
\begin{aligned}
& m^{*}=\left[x_{1}^{*}, x_{2}^{*}, \ldots \ldots \ldots x_{k}^{*}\right] \text { (maksimum değerler) (3) } \\
& m^{-}=\left[x_{1}^{-}, x_{2}^{-}, \ldots \ldots \ldots x_{n}^{-}\right] \text {(minimum değerler) (4) }
\end{aligned}
$$

5. Adım: Maksimum İdeal Noktaya Olan Uzaklığın Hesaplanması $\left(S_{i}^{*}\right)$

$$
S_{i}^{*}=\sqrt{\sum_{j=1}^{k}\left(x_{i j}-x_{j}^{*}\right)} i=1 \ldots \ldots \ldots n(5)
$$

6. Adım: Minimum Noktaya Olan Uzaklığın Hesaplanması $\left(S_{i}^{-}\right)$

$$
S_{i}^{-}=\sqrt{\sum_{j=1}^{k}\left(x_{i j}-x_{j}^{-}\right)} i=1 \ldots \ldots \ldots n
$$

7. Adım: Her bir alternatifin Göreceli Siralamasının Oluşturulması Ve Puanlarının Hesaplanması $\left(C_{i}^{*}\right)$

$$
C_{i}^{*}=\frac{s_{i}^{-}}{s_{i}^{-}+S_{i}^{*}} \quad 0 \leq C_{i}^{*} \leq 1 i=1 \ldots \ldots \ldots n
$$

Sisteme kabul edilecek torpido seçimi için Topsis yönteminden yararlanılmıştır. Torpidoların kapasiteleri ve 1'den 10'a kadar verilen torpido kullanılabilirliği derecesi ile hesaplama yapılmıştır. Kullanılabilirlik derecesi torpidonun bundan sonraki kullanım ömrü ve kullanım kalitesine göre puanlanmıştır. Tablo 8'de gösterildiği gibi kullanılabilirliği yüksek olana 10 puan verilirken, kullanılamaz durumda olana ise 1 puan verilerek torpido kullanılabilirliği puanlama tablosu oluşturulmuştur.

Tablo 10. Torpido Kullanılabilirliği Puanlama Tablosu

\begin{tabular}{lr}
\hline Kullanıla Bilirliği & Derecesi \\
\hline Oldukça Yüksek & 10 \\
Çok Yüksek & 9 \\
Yüksek & 8 \\
Kismen Yüksek & 7 \\
Kısmen Orta & 6 \\
Orta & 5 \\
Kısmen Düşük & 4 \\
Düşük & 3 \\
Çok Düşük & 2 \\
Hemen Hemen Olanaksız & 1 \\
\hline
\end{tabular}


Uygulama 1. Adım: Karar matrisinin oluşturulması için karar matrisinin satırlarında üstünlükleri sıralanmak istenen karar noktaları, sütunlarında ise karar vermede kullanılacak değerlendirme faktörleri yer almaktadır. Karar matrisi karar verici tarafından oluşturulan başlangıç matrisidir. Karar matrisi aşağıda sunulan Tablo 9'da gösterilmiştir.

Tablo 11.Topsis Karar Matrisi

\begin{tabular}{ccc}
\hline ALTERNATİFLER & $\begin{array}{c}\text { ÖZELLIKLER } \\
\text { Torpido } \\
\text { Kapasitesi } \\
\text { (Ton) }\end{array}$ & $\begin{array}{c}\text { Kullanılabilirlik } \\
\text { Derecesi }\end{array}$ \\
\hline 4.torpido & 144,67 & 9 \\
5.torpido & 102,56 & 4 \\
6.torpido & 149,49 & 10 \\
8.torpido & 107,47 & 5 \\
10.torpido & 141,08 & 9 \\
11.torpido & 140,24 & 8 \\
12.torpido & 155,16 & 10 \\
13.torpido & 101,94 & 6 \\
14.torpido & 74,13 & 3 \\
16.torpido & 144,83 & 9 \\
18.torpido & 65,08 & 4 \\
\hline
\end{tabular}

Uygulama 2. Adım: Normalize karar matrisinin oluşturulması için Denklem (1) de görüldüğü gibi sütunlardaki her değer o sütünün değerlerin karelerinin toplamının kareköküne bölünür. Topsis Normalize Karar Matrisi Tablo 10'da gösterilmiştir.

Tablo 12.Topsis Normalize Karar Matrisi

\begin{tabular}{ccc}
\hline Torpido No & $\begin{array}{c}\text { Torpido } \\
\text { Kapasitesi }\end{array}$ & Kullanılabilirlik Derecesi \\
\hline 4.torpido & 0,351 & 0,365 \\
5.torpido & 0,249 & 0,162 \\
6.torpido & 0,362 & 0,405 \\
8.torpido & 0,261 & 0,203 \\
10.torpido & 0,342 & 0,365 \\
11.torpido & 0,340 & 0,324 \\
12.torpido & 0,376 & 0,405 \\
13.torpido & 0,247 & 0,243 \\
14.torpido & 0,180 & 0,122 \\
16.torpido & 0,351 & 0,365 \\
18.torpido & 0,158 & 0,162 \\
\hline
\end{tabular}

Uygulama 3. Adım: Ağırlıklandırılmış normalize karar matrisinin oluşturulması için normalize karar matrisindeki ilgili özellik ağırlığı ile çarpılır. Torpido kapasitesinin ağırlığı 0,5 ve kullanılabilirlik derecesinin ağırlığ 0,5 olarak belirlenmiştir. Bunun sebebi iki kriterin, alternatiflerin seçiminde eşit derecede etkili olmasıdır. Denklem (2) kullanılarak her bir değer ağırlıkları ile çarpılarak Tablo 11'deki ağırlıklandırılmış normalize karar matrisi oluşturulmuştur.

Uygulama 4. Adım: $m^{*}$ ve $m^{-}$değerleri Denklem (3-4) ağırlıklandırılmış normalize karar matrisinde her bir sütundaki maksimum ve minimum değerleridir. Tablo 12 'de görüldüğü gibi torpido Kapasitesi sütunundaki maksimum değer 0,188'dir. Kullanılabilirlik Derecesi sütunundaki maksimum değer ise 0,203 'dür. Torpido Kapasitesi sütunundaki minimum değer 0,079 'dur. Kullanılabilirlik Derecesi sütunundaki minimum değer ise 0,061 'dir.

Tablo 13.Topsis Ağırlıklandırılmış Normalize Karar Matrisi

\begin{tabular}{lrr}
\hline \multicolumn{3}{c}{ Matrisi } \\
\hline Torpido No & Torpido Kapasitesi & $\begin{array}{c}\text { Kullanılabilirlik } \\
\text { Derecesi }\end{array}$ \\
\hline 4.torpido & 0,175 & 0,182 \\
5.torpido & 0,124 & 0,081 \\
6.torpido & 0,181 & 0,203 \\
8.torpido & 0,130 & 0,101 \\
10.torpido & 0,171 & 0,182 \\
11.torpido & 0,170 & 0,162 \\
12.torpido & 0,188 & 0,203 \\
13.torpido & 0,124 & 0,122 \\
14.torpido & 0,090 & 0,061 \\
16.torpido & 0,176 & 0,182 \\
18.torpido & 0,079 & 0,081 \\
\hline
\end{tabular}

Tablo 14.Topsis Maksimum Ve Minimum Değerler

\begin{tabular}{lcc}
\hline & $\begin{array}{c}\text { Torpido } \\
\text { Kapasitesi }\end{array}$ & $\begin{array}{c}\text { Kullanılabilirlik } \\
\text { Derecesi }\end{array}$ \\
\hline$m^{*}$ MaksimumDeğerler & 0,188 & 0,203 \\
$m^{-}$Minimum Değerler & 0,079 & 0,061 \\
\hline
\end{tabular}

Uygulama 5. ve 6. Adım: Maksimum ideal noktaya olan uzaklık $\left(S_{i}^{*}\right)$ Denklem (5) ve minimum noktaya olan uzaklık $\left(S_{i}^{-}\right)$Denklem (6) kullanılarak hesaplanmıştır ve Tablo 13'te verilmiştir.

\begin{tabular}{ccc}
\multicolumn{3}{c}{ Tablo 15.Topsis $S_{i}^{*} \mathrm{ve} S_{i}^{-}$Değerleri } \\
\hline Torpido No & $S_{i}^{*}$ & $S_{i}^{-}$ \\
\hline 4.torpido & 0,024 & 0,155 \\
5.torpido & 0,137 & 0,050 \\
6.torpido & 0,007 & 0,175 \\
8.torpido & 0,117 & 0,065 \\
10.torpido & 0,026 & 0,153 \\
11.torpido & 0,044 & 0,136 \\
12.torpido & 0,000 & 0,179 \\
13.torpido & 0,104 & 0,075 \\
14.torpido & 0,173 & 0,011 \\
16.torpido & 0,024 & 0,155 \\
18.torpido & 0,163 & 0,020 \\
\hline
\end{tabular}

Uygulama 7. Adım: Hesaplanan ideal ve negatif ideal çözüm değerleri kullanılarak ideal çözüme göreli yakınlık değeri $C_{i}^{*}$ Denklem (7) kullanılarak hesaplanmıştır. $C_{i}^{*}$ değerleri büyükten küçüğe doğru sıralanmıştır ve çözüme en yakın değer en büyük değer anlamına gelmektedir. Tablo 14 'te Topsis yönteminde elde edilen $C_{i}^{*}$ değerleri büyükten küçüğe doğru sıralanarak verilmiştir.

Çıkan sonuçlar doğrultusunda $C_{i}^{*}$ değeri 0,5 'den küçük olanlar sisteme alınmayacak iken 0,5 'den büyük olanlar sisteme kabul edilecektir. Bunun sebebi sisteme kabul edilecek torpido sayılarını azaltılmasıdır. Matematiksel olarak bir sınır konulmuştur ve bu sinır 0,5 olarak temel alınmıştır. Bu doğrultuda 12, 6, 16, 4, 10 ve 11 numaralı torpidolar sisteme alınacak iken $13,8,5,18$ ve 14 numaralı torpidolara sisteme alınmayacaktır. 


\begin{tabular}{lcrr}
\multicolumn{4}{c}{ Tablo 16.Topsis $C_{i}^{*}$ Değerleri } \\
\hline Torpido No & $\begin{array}{c}\text { Torpido } \\
\text { Kapasitesi } \\
\text { (Ton) }\end{array}$ & $\begin{array}{c}\text { Kullanılabilirlik } \\
\text { Derecesi }\end{array}$ & $\boldsymbol{C}_{\boldsymbol{i}}^{*}$ \\
\hline 12.torpido & 155,158 & 10 & $\mathbf{1}$ \\
6.torpido & 149,486 & 10 & $\mathbf{0 , 9 6 2}$ \\
16.torpido & 144,829 & 9 & $\mathbf{0 , 8 6 7}$ \\
4.torpido & 144,667 & 9 & $\mathbf{0 , 8 6 6}$ \\
10.torpido & 141,083 & 9 & $\mathbf{0 , 8 5 2}$ \\
11.torpido & 140,237 & 8 & $\mathbf{0 , 7 5 4}$ \\
13.torpido & 101,939 & 6 & $\mathbf{0 , 4 2 1}$ \\
8.torpido & 107,474 & 5 & $\mathbf{0 , 3 5 9}$ \\
5.torpido & 102,559 & 4 & $\mathbf{0 , 2 6 6}$ \\
18.torpido & 65,081 & 4 & $\mathbf{0 , 1 1 0}$ \\
14.torpido & 74,132 & 3 & $\mathbf{0 , 0 6 0}$ \\
\hline
\end{tabular}

\section{2 ÖNERILEN SENARYO}

Sisteme kabul edilecek torpidolar Topsis yöntemi ile seçildikten sonra senaryo analiz edilmiştir. 12, 6, 16, 4, 10 ve 11 numaralı torpidolar sisteme alınmıştır. $13,8,5,18$ ve 14 numaralı torpidolar sisteme alınmamıştır ve yeni durumda sistemin tartışılmıştır. Önerilen senaryonun benzetim şeması Şekil 6'daki gibidir. Yüksek firınlarda oluşan kuyruk bekleme sürelerinin azaltılması için yeni bir karar eklenerek kuyruk uzunluğu ve işlem gören torpido sayısı az olan firını seçilecek şekilde karar formülleri yazılmıştır. 5. fırının kapasitesi diğerlerine göre daha fazla olduğu için ilk seçim kararı 5. fırına gönderilmiştir. Kararları sağlamayan durumlarda torpido 1 . firına gönderilmektedir.

Mevcut sistemde firınlarda döküm açıldıkça rastgele torpido çağırılmaktadır. Torpidolar hangi fırınlara gönderileceği kararı yüzdelik varsayımlara göre yapılırken önerilen senaryoda sisteme kabul edilen torpidoların olduğu verilerdeki oran tekrar hesaplanarak acil istenen torpidolar $\% 9,9$ ile 1. Fırına, \%27,23 ile 3. firına, \%17,82 ile 4. firına geri kalan kısım ise 5. firına gönderilmektedir. Bu şekilde sistem tekrar modellenmiştir ve benzetim modeli 31 gün çalıştırılmıştır. Önerilen senaryonun dağılımları Tablo 15'de ve karar yüzdeleri Tablo 16'da verilmiştir.

Tablo 17. Önerilen Senaryonun Dağ 11 imları

\begin{tabular}{|c|c|}
\hline Süreler & Dağılım \\
\hline Torpido GAS & 0,0 \\
\hline 1.Fırın İşlem Süresi & $39+144 * \operatorname{BETA}(0,6371,33)$ \\
\hline 3.Fırın İşlem Süresi & $19.5+84 * \operatorname{BETA}(2,351,56)$ \\
\hline 4.Fırın İşlem Süresi & $\operatorname{NORM}(79,126,1)$ \\
\hline 5.Fırın İşlem Süresi & $18+\operatorname{ERLA}(14,8$ 2) \\
\hline Kükürt Giderme İşlemi Süresi & $5.5+\operatorname{ERLA}(5,083)$ \\
\hline Maden Aktarma İșlemi Süresi & $7.5+\operatorname{ERLA}(8,234)$ \\
\hline Kişpit İșlem Süresi & $3.5+\operatorname{LOGN}(17,914,8)$ \\
\hline
\end{tabular}

Tablo 18. Önerilen Senaryonun Karar Yüzdeleri

\begin{tabular}{lc}
\hline Karar Adı & Yüzdesi (\%) \\
\hline III. Karar Torpido Dolu & 99,9 \\
III. Karar Torpido Tam Dolu Değil & 0,01 \\
IV. Karar Fırınlar Acil Torpido Bekliyor & 11,88 \\
IV. Karar Fırınlar Acil Torpido Beklemiyor & 88,12 \\
V. Karar Torpido Kişpite Gönderilecek & 87,62 \\
V. Karar Torpido Kişpite Gönderilmeyecek & 12,38 \\
VI. Karar 1.Fırın & 9,9
\end{tabular}

VI. Karar 3.Firın $\quad 27,23$

VI. Karar 4.Firin $\quad 17,82$

\begin{tabular}{lr} 
VI. Karar 5.Firın $\quad 45,05$ \\
\hline
\end{tabular}

Tablo 17'de görüldüğü gibi oluşturulan yeni senaryoda 5 . firın 582 adet torpido dolum işlemi gerçekleştirmiştir. En çok torpido dolduran firın mevcut durumdaki gibi 5.firın olarak çıkmıştır. En az torpido dolduran fırın ise 47 adet torpido dolumu gerçekleştiren 1. firındır. Kükürt gidermede işlem gören torpido sayısı ise 1.092 adettir. Maden aktarma çukurlarında işlem gören torpido sayısı 1.090 adet olarak çıkmıştır. Kişpit istasyonunda işlem gören torpido sayısı ise 826 adettir. Toplam işlem gören yanı maden aktarma çukurlarına kadar gelip madeni boşaltan torpido sayısı ise 1.090 adettir.

Tablo 19. Önerilen Senaryoda İşlem Gören Torpido Sayıları

\begin{tabular}{lr}
\hline Sayaç Adı & $\begin{array}{c}\text { Değer } \\
\text { (Adet) }\end{array}$ \\
\hline 1.Fırında İşlem Gören Torpido Sayısı & 47 \\
3.Fırında İslem Gören Torpido Sayısı & 163 \\
4.Fırında İşlem Gören Torpido Sayısı & 301 \\
5.Fırında İşlem Gören Torpido Sayısı & 582 \\
Kükürt Gidermede İşlem Gören Torpido Sayısı & 1092 \\
Maden Aktarmada İşlem Gören Torpido Sayısı & 1090 \\
Kişpit’te İşlem Gören Torpido Sayısı & 826 \\
\hline
\end{tabular}

Tablo 18'de gösterildiği gibi yeni senaryoda torpidolar ayrı ayrı kaç kez maden boşalttığı sayılmıştır. En çok maden boşaltma sayısı 6 . ve 10. torpido 182 adet iken en az maden boşaltma sayısı 12. torpido ile 178 adettir. Torpidoların her birinin taşıyabileceği sıvı ham demir miktarı farklıdır. En çok maden taşıyan 12. torpido iken en az maden taşıyan ise 11. torpido olmuştur. 31 günlük çalışma sonucunda toplam dökülen maden miktarı ise 159.006,38 ton olarak hesaplanmıştır.

Tablo 20. Önerilen Senaryoda Döküm Sayısı

\begin{tabular}{lccr}
\hline Torpido & $\begin{array}{c}\text { Kapasite } \\
\text { (Ton) }\end{array}$ & $\begin{array}{c}\text { Döküm } \\
\text { Sayısı } \\
\text { (Adet) }\end{array}$ & $\begin{array}{c}\text { Toplam Dökülen } \\
\text { Demir Miktarı } \\
\text { (Ton) }\end{array}$ \\
\hline 4.torpido & 144,67 & 182 & $26.329,94$ \\
6.torpido & 149,49 & 184 & $27.506,16$ \\
10.torpido & 141,08 & 184 & $25.958,72$ \\
11.torpido & 140,24 & 182 & $25.523,68$ \\
12.torpido & 155,16 & 178 & $27.618,48$ \\
16.torpido & 144,83 & 180 & $26.069,4$ \\
Toplam & & & $159.006,38$ \\
\hline
\end{tabular}

Önerilen senaryoda kuyruk bekleme süreleri Tablo 19'da gösterilmiştir. 1. firındaki bekleme süresi tamamen azalarak sıfira kadar düşmüştür. Diğer firınlardaki bekleme sürelerinde de mevcut duruma kıyasla düşüşler gerçekleşmiştir. Yine mevcut durumdaki gibi en çok bekleme süresine sahip olan istasyon Maden Aktarma Çukurlarıdır. Fakat mevcut sistem ile kıyaslandığında büyük bir miktarda azalma görülmektedir. Toplam bekleme süresi ise 109,98 dakika olmuştur. Benzetim sonucunda, mevcut sistemde oluşan toplam kuyruk bekleme süresinin oldukça azaldığı görülmüştür. 


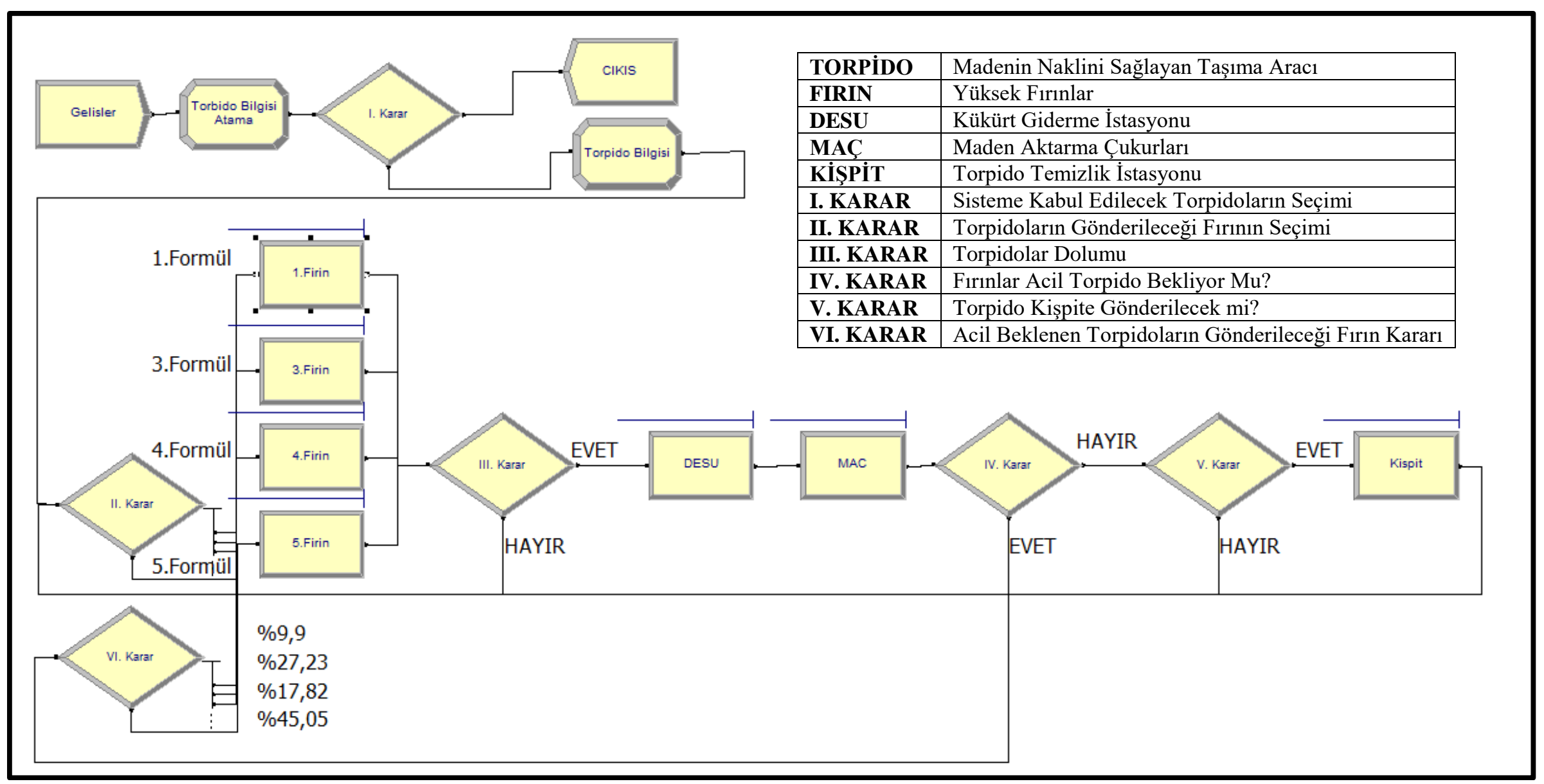

Şekil 6. Önerilen Torpido Taşıma Sistemi Senaryosu Benzetim Modeli Şematik Gösterim 
Tablo 21. Önerilen Senaryoda Kuyruk Bekleme Süreleri

\begin{tabular}{lr}
\hline Kuyruk Adı & $\begin{array}{c}\text { Kuyrukta Bekleme } \\
\text { Süresi (Dakika) }\end{array}$ \\
\hline 1.Fırının Kuyruğu & 0,0 \\
3.Fırının Kuyruğu & 1,80 \\
4.Fırının Kuyruğu & 1,29 \\
5.Fırının Kuyruğu & 1,38 \\
Kükürt Giderme İşlemi Kuyruğu & 5,26 \\
Maden Aktarma İşlemi Kuyruğu & 98,02 \\
Kişsit Kuyruğu & 2,23 \\
\hline Toplam Bekleme Süresi & 109,98 \\
\hline
\end{tabular}

\section{SONUÇLAR}

Çalışma sonucunda mevcut durum ile önerilen senaryo birbiri ile kıyaslanmıştır. İlk benzetim mevcut durumun modellenmesi ile çalıştırılmıştır. İkinci önerilen benzetim ise darboğaz oluşturan torpidoların çıkartılarak ve firınlar için uygun formüller yazılarak oluşturulan benzetimdir. İki uygulama sonucu çıkan kuyruk bekleme süreleri Tablo 20 ve Tablo 21'de verilmiştir.

Mevcut durumda kuyrukta bekleme süresi 1. firında 21,55 dakika iken yeni senaryoda hiç bekleme olmamıştır. 3 . firındaki mevcut durumda bekleme süresi 13,07 dakika iken yeni senaryoda bekleme süresi 1,80 dakikaya kadar düşmüştür.

Mevcut durumda darboğaz sorununun oluştuğu maden aktarma çukurlarında 235,50 dakika bekleme süresi oluşurken yeni senaryoda maden aktarma çukurlarındaki bekleme süresi 98,02 dakikaya kadar düşmüştür.

Mevcut durumdaki torpido taşıma sisteminde toplamda oluşan bekleme süresi 326,87 iken oluşturulan yeni senaryoda 109,98 dakikaya kadar düşmüştür. Yeni senaryoda 216,89 dakika ile \%66,35 oranında kayıp zaman geri kazandırılmıştır. Böylece sistem daha verimli hale getirilmiştir.

Mevcut durumda taşınan sıvı ham demir 145.791,05 ton iken yeni senaryoda taşınan sıvı ham demir \%9,06 oranında artarak toplam maden aktarma çukurlarına 159.006,38 ton sıvı ham demir boşaltılmıştır. Önerilen senaryo ile 13.215,33 ton sıvı ham demir kazancı sağlanmıştır.

Tablo 22. Mevcut Durumda Kuyrukta Bekleme Süreleri

\begin{tabular}{lr}
\hline Kuyruk Adı & $\begin{array}{c}\text { Kuyrukta Bekleme } \\
\text { Süresi (Dakika) }\end{array}$ \\
\hline 1.Fırının Kuyruğu & 21,55 \\
3.Fırının Kuyruğu & 13,07 \\
4.Fırının Kuyruğu & 10,96 \\
5.Fırının Kuyruğu & 21,29 \\
Kükürt Giderme İşlemi Kuyruğu & 7,23 \\
Maden Aktarma İşlemi Kuyruğu & 235,50 \\
Kişpit Kuyruğu & 17,27 \\
\hline Toplam Bekleme Süresi & 326,87 \\
\hline
\end{tabular}

Tablo 23. Önerilen Senaryoda Kuyrukta bekleme Süreleri

\begin{tabular}{lr}
\hline Kuyruk Adı & \multicolumn{1}{c}{$\begin{array}{c}\text { Önerilen Senaryoda } \\
\text { Kuyrukta Bekleme } \\
\text { Süresi (Dakika) }\end{array}$} \\
\hline 1.Fırının Kuyruğu & 0 \\
3.Fırının Kuyruğu & 1,80 \\
4.Fırının Kuyruğu & 1,29 \\
5.Fırının Kuyruğu & 1,38 \\
Kükürt Giderme İşlemi Kuyruğu & 5,26 \\
Maden Aktarma İşlemi Kuyruğu & 98,02 \\
Kişpit Kuyruğu & 2,23 \\
\hline Toplam Bekleme Süresi & 109,98 \\
\hline
\end{tabular}

\section{TARTIŞMA}

Günümüz şartlarında demir-çelik sektörü başta olmak üzere tüm sektörlerde verimlilik her geçen gün artan bir öneme sahip olmaktadır. Kaynakların en verimli şekilde kullanılması, zaman kayıplarının minimuma indirilmesi, iç ve dış nakliye faaliyetlerinin en verimli hale getirilebilmesi hedeflenmektedir. Müşteri istek ve davranışları bu yönde ilerlemekte ve müşteriler kaliteli, esnek ve hılı üretim yapabilen firmaları tercih etmektedirler.

$\mathrm{Bu}$ amaçla yola çıkılarak sistem içerisindeki zaman kayıplarını minimize edebilmeyi sağlayan bir çalışma üzerinde durulmuştur. Yapılan çalışmada, demir-çelik sektöründe sıvı ham demir nakil sürecinin gerçekleştirilmesi sırasında ortaya çıkan darboğazlar tespit edilmiştir ve bu darboğazların ortadan kaldırılmasına yönelik kararların çok kriterli olarak verilmesi önerilmiştir.

Sonuç olarak, mevcut durumda maden aktarma çukurlarında 235,50 dakika bekleme süresi oluşurken yeni durumda 98,02 dakikaya kadar düşmüştür. Yeni durum ile tüm süreçlerin toplaminda 216,89 dakikalı zaman sisteme geri kazandırılmıştır. Böylece sistem \%66,35 oranında kayıp zamanını geri kazanmıştır. Mevcut durumda taşınan sıvı ham demir ise 145.791,05 ton iken yeni modelde \%9,06 oranında artarak toplamda maden aktarma çukurlarına 159.006,38 ton Sıvı ham demir boşaltılmıştır. Önerilen yöntem ile 13.215,33 ton sıvı ham demir kazanç sağlanmıştır.

Çalışmamızda üretim ve taşıma sistemi değerlendirilirken gözlenen verilerin sistemin karakteristiklerini yansıtmasına özen gösterilmiştir. Torpidolar için ağırlık kriterleri belirlenirken uzman kişilerin öznel yargılarından yararlanılmıştır. Değerlendirmemiz bu sayede hem nesnel hem de öznel verileri yansitmaktadır. $\mathrm{Bu}$ yönüyle çalışmamız sistem içerisindeki ürün taşıma sürecinin analiz edilmesi alanında yapılacak sonraki çalışmalara örnek teşkil edebilecektir.

Benzetim modellemede kullanılacak olan dağılımları belirlemek için verilerin yılın tamamında toplanması çalışmanın yaygın etkisini ortaya çıkaracaktır. Nakil süreci içerisinde oluşabilecek kaza ve duruşlar için yıllık verilerin kullanılması daha güvenilir dağılımlar elde etmeyi sağlayacaktır. 
Gelecek çalışmalarda, firın kapasiteleri, maden aktarma çukurlarının kapasiteleri, kullanılan refrakterin aşınmadaki etkisi (torpidoların ömrünü ve kapasitesini etkilemesi), gibi kriterler doğrultusunda darboğazlara yönelik yeni önerilerde bulunulabilir. Ayrıca çalışmaya maliyet kriterleri eklenerek sistemden elde edilen parasal kazanç hesabı yapılabileceği gibi sektörde kullanılan diğer taşıma süreçlerinde de bu çalışmaya paralel iyileştirmeler yapılması yeni bir araştırma konusu olabilir.

\section{KAYNAKÇA}

[1] M. Küçükönder, M. Uçar, "Üretim Etkinliğinde Simülasyon", Kahramanmaraş Sütçü İmam Üniversitesi İktisadi Ve İdari Bilimler Fakültesi Dergisi, Cilt 5, Say1 1, ss. 117-126, (2015).

[2] E. Sabır, E. Batuk, "Modeling Of Textile DyeingFinishing Mill Production Cost And Time Under Variable Demand Conditions With Simulation", Tekstil Ve Konfeksiyon, Cilt 24, Say1 4, ss. 371-379, (2014).

[3] H. Koruca, "Simülasyon Destekli Vardiya Planlama Modülü Geliştirilmesi”. Gazi Üniversitesi MühendislikMimarlık Fakültesi Dergisi, Cilt 25, Sayı 3, ss. 469-482, (2013).

[4] M. Gül, E. Çelik, A.F. Güneri A.F, A.T. Gümüş, "Simülasyon ile bütünleşik çok kriterli karar verme: Bir hastane acil departmanı için senaryo seçimi uygulaması". İstanbul Ticaret Üniversitesi Fen Bilimleri Dergisi, Cilt 11, Say1 22, ss. 1-18, (2012).

[5] T. Boyraz "Döküm depodan tugaya akaryakıt dağıtım sisteminin simülasyonu ve analizi”. Afyon Kocatepe Üniversitesi İktisadi ve İdari Bilimler Fakültesi Dergisi, Cilt 16, Say1 2, ss. 105-117, (2014).

[6] S. Kurşun, "Tekstil endüstrisinde benzetim tekniği ile üretim hattı modellemesi ve uygun iş akış stratejisinin belirlenmesi”. İTÜ, Fen Bilimleri Enstitüsü, Yüksek Lisans Tezi, İstanbul, (2007).

[7] M. Bağ, E. Aslan, "Bir Tekstil Fabrikasında Simülasyon Uygulaması". Journal of International Management Educational and Economics Perspectives, Cilt 4, Say1 1, ss. 38-54, (2016).

[8] Ö. Uner, C. Özkale, Z. Aladağ, B.Y. Yazgan, "Üretim Sistemi Tasarımında Konveyörlü Taşıma Alternatiflerinin Simülasyon Yöntemiyle Değerlendirilmesi”. İstanbul Ticaret Üniversitesi Fen Bilimleri Dergisi, Cilt 4, Say1 8, ss. 49-73, (2005).

[9] Y. Kuvvetli, R. Erol, “Ağaç Ürünleri Üreten Bir İşletmede Malzeme Taşıma Sisteminin Simülasyon Yaklaşımıyla İyileştirilmesi”, Çukurova Üniversitesi Mühendislik Mimarlık Fakültesi Dergisi, Cilt 32, Sayı 1, ss. 215-222, (2017).
[10] O. Oleghe, K. Salonitis, "Hybrid simulation modelling of the human-production process interface in lean manufacturing systems", International Journal of Lean Six Sigma, vol. 10 No. 2, pp. 665-690, (2019).

[11] M. Çolak, G.A. Keskin, H. Esen, C. Bektaş. A Simulation Based Approach for Efficient Yard Planning in a Container Port. Süleyman Demirel Üniversitesi Fen Bilimleri Enstitüsü Dergisi, Cilt 22, Sayı 3, ss. 1157-1164, (2018).

[12] T. P. Fredman J. Torrkulla, H. Saxén, “Twodimensional dynamic simulation of the thermalstate of ladles", Metallurgical and Materials Transactions B, vol. 30, Issue 2, pp 323-330, (1999).

[13] A. Guasch, J.F. i Jove, P.F. i Casas, "Factory Railway System", In Simulation-Based Case Studies in Logistics, In: Simulation-Based Case Studies in Logistics. Springer, pp 118, London, (2009).

[14] G. Neumann, "Material Handling System", In: Simulation-Based Case Studies in Logistics. Springer, pp 167-188, London, (2009).

[15] L. Yao, W. Zhu, "Visual simulation framework of iron and steel production scheduling based on Flexsim", In 2010 IEEE Fifth International Conference on Bio-Inspired Computing: Theoriesand Applications (BIC-TA), Changsha, China, (2010).

[16] R. J. Coelho, P. F. Lana, A. C. Silva, T. F. Santos, A. Tubarão, M. M. Fioroni, ... \& L.B. da Silva, "Operational simulation model of the raw material handling in an integrated steel making plant", In Winter Simulation Conference, pp. 3055-3065, (2009).

[17] A. Mukherjee, A. Som, A. Adak, P. Raj, S. Kirtania, "Augmenting an inbound raw material handling system of a steel plant by uncovering hidden logistics capacity", Proceedings of the 2012 Winter Simulation Conference (WSC), Berlin, Germany, (2012).

[18] C. Çörekçi, "Atölye Tipi Üretimde Simülasyon Teknikleri İle Dinamik Çizelgeleme Ve Atölye Simülasyonu." Yüksek Lisans Tezi Kırıkkale Üniversitesi, Kirikkale, (2014).

[19] B., Dursun, “Topsis Ve Electre Yöntemi İle Tedarikçi Seçimi: Kozmetik Sektöründe Bir Uygulama" Yüksek Lisans Tezi, Bahçeşehir Üniversitesi, İstanbul, (2018).

[20] T. Genç, M. Masca. "Topsis ve Promethee Yöntemleri ile Elde Edilen Üstünlük Siralamalarının Bir Uygulama Üzerinden Karşılaştırılması”. Afyon Kocatepe Üniversitesi İktisadi ve İdari Bilimler Fakültesi Dergisi, Cilt 15, Sayı 2, ss. 539-567, (2013).

[21] İ. Ertuğrul, A. Özçil, “Çok Kriterli Karar Vermede TOPSIS ve VIKOR Yöntemleriyle Klima Seçimi” Çankırı Karatekin Üniversitesi İktisadi ve İdari Bilimler Fakültesi Dergisi, Cilt 4, Say1 1, ss. 267- 282, (2014.) 